\title{
Analysis of adverse events of sunitinib in patients treated for advanced renal cell carcinoma
}

\author{
Małgorzata Domagała-Haduch, Ida Cedrych, Marek Jasiówka, Maciej Niemiec, Piotr Skotnicki
}

Maria Sklodowska-Curie Memorial Cancer Center and Institute of Oncology, Krakow Branch, Krakow, Poland

Submitted: 12 August 2014

Accepted: 25 November 2014

Arch Med Sci 2016; 12, 2: 360-364

DOI: 10.5114/aoms.2016.59262

Copyright @ 2016 Termedia \& Banach

\section{Abstract}

Introduction: Treatment of the metastatic stage of renal cell carcinoma is specific because classical chemotherapy is not applicable here. The treatment is mainly based on molecularly targeted drugs, including inhibitors of tyrosine kinases. In many cases the therapy takes many months, and patients often report to general practitioners due to adverse events. In this article, the effectiveness and side effects of one of these drugs are presented. The aim of the study was to analyse of the toxicity and safety of treatment with sunitinib malate in patients with clear cell renal cell carcinoma in the metastatic stage. Material and methods: Adverse events were analyzed using retrospective analysis of data collected in a group of 39 patients treated in the Department of Systemic and Generalized Malignancies in the Cancer Center in Krakow, Poland.

Results: Toxicity of treatment affected $50 \%$ of patients. The most common side effects observed were hypertension, thrombocytopenia, stomatitis, diarrhea and weakness. Grade 3 serious adverse events according to Common Terminology Criteria for Adverse Events (CTCAE) version 4 affected up to $10 \%$ of patients. The most common serious adverse events were hypertension and fatigue.

Conclusions: Sunitinib malate is characterized by a particular type of toxicity. Knowledge of the types and range of adverse events of this drug is an important part of oncological and internal medicine care.

Key words: sunitinib, renal cell carcinoma, adverse events, treatment time to progression, toxicity of treatment.

\section{Introduction}

Kidney cancer accounts for 2-3\% of all malignant tumors. Eighty percent of cases occur after the age of 40, and the incidence rate for men compared with women is 3 : 2; in 2009 the National Cancer Registry recorded 2,733 cases among men and 1,866 cases among women [1].

Kidney cancer is often asymptomatic, resulting in late diagnosis. More than half of tumors are detected incidentally in imaging studies. The rest cause discrete symptoms such as fatigue, low-grade fever, and recurrent inflammation of the urinary tract. The classic triad of symptoms (Virchow's triad) - hematuria, flank pain and a palpable tumor - occurs in $6-10 \%$ of patients [2].

The World Health Organization (WHO) classifies kidney cancer according to its pathomorphology [3].

\author{
Corresponding author: \\ Małgorzata Domagała- \\ Haduch \\ Maria Sklodowska-Curie \\ Memorial Cancer Center \\ and Institute of Oncology \\ 11 Garncarska St \\ 31-115 Krakow, Poland \\ Phone: +48126348350 \\ E-mail: malgorzatadom@ \\ interia.pl
}




\section{Staging and prognosis}

The clinical stage of kidney cancer was determined by TNM classification ( $7^{\text {th }}$ edition, 2010) [4]. The prognosis was determined according to the Motzer scale of the Memorial Sloan Kettering Cancer Center (MSKCC), which was created by Motzer et al. to determine the survival prognosis of patients. Today, it is also used to select an appropriate therapy [5].

Nephrectomy or kidney-sparing surgery should be considered for each patient. In the early stages of the disease, it allows recovery and in metastatic kidney cancer it prolongs survival $[6,7]$.

\section{Systemic treatment}

Molecularly targeted drugs and interferon alpha are used today in the treatment of kidney cancer. Patients with a good prognosis according to the MSKCC scale, after nephrectomy and with metastases in the lungs only, are qualified for immunotherapy with interferon.

Sunitinib malate is a small molecule inhibitor of multiple receptor tyrosine kinases, including platelet-derived growth factor receptors $\alpha$ and $\beta$, vascular endothelial growth factor (type 1, 2 and 3), Fms-like tyrosine kinase 3 receptor, stem cell factor receptors, glial cell line-derived neurotrophic factor receptors, and colony-stimulating factor receptors.

In 2009, the results of a third phase trial were published; its aim was to compare the efficacy of interferon $\alpha$ and sunitinib as first-line treatment of patients with clear cell renal cell carcinoma with metastases. In the group of patients treated with sunitinib, $47 \%$ of patients achieved an objective response to treatment; in the group treated with interferon $\alpha$, an objective response was achieved in $12 \%$ of patients. Median progression-free survival (PFS) was 11 months for sunitinib and 5 months for interferon $\alpha$. Median overall survival (OS) was 26.7 months for sunitinib and 23.7 months for interferon $\alpha$. Twenty percent of patients receiving sunitinib and $23 \%$ of patients treated with interferon $\alpha$ discontinued the treatment because of adverse reactions [8].

Table I. Classification of patients according to the Motzer scale

\begin{tabular}{|lcc|}
\hline Number of factors & $\begin{array}{c}\text { Number } \\
\text { of patients }\end{array}$ & $\begin{array}{c}\text { Percentage } \\
\text { of patients }\end{array}$ \\
\hline 0 & 16 & 41.0 \\
\hline 1 & 11 & 28.2 \\
\hline 2 & 9 & 23.1 \\
\hline 3 & 3 & 7.7 \\
\hline
\end{tabular}

The National Comprehensive Cancer Network, the National Cancer Institute and the Polish Union of Oncology recommend using sunitinib in the first-line treatment of patients with favorable and intermediate prognosis ( $0-2$ risk factors according to the Motzer scale) for metastatic renal cell carcinoma [9-12].

Standard dosing of sunitinib is $50 \mathrm{mg} /$ day for 4 weeks, and then it is stopped for 2 weeks.

\section{Material and methods}

We analyzed the data of 39 patients with a diagnosis of clear cell renal cell carcinoma treated with sunitinib malate at the Cancer Center in Krakow, Poland, between 2007 and 2012. In all patients, the disease was at the metastatic stage.

\section{Results}

Table I presents the classification of patients due to predictors, according to the MSKCC scale. $51.3 \%$ (20 patients) were male and $48.7 \%$ (19) were female. The average age at diagnosis of metastatic disease was 62.6 years (range: $41-81$ years). Table II presents the classification of patients by site of the metastases.

The median time from diagnosis of renal cell carcinoma to metastasis was 18.1 months. All patients underwent nephrectomy before receiving sunitinib.

In 30 (77\%) patients, metastases were observed in more than one place. None of the patients had metastases in the central nervous system.

Twenty-three patients stopped therapy because of: disease progression in 14 patients, adverse events in 8 patients, 1 patient was lost to follow-up.

The occurrence of adverse events was analyzed using information from the physical examination as well as laboratory tests and imaging.

The median follow-up was 31.3 months (range: 17.3-32.6 months). The median duration of treatment was 6.3 months (range: 0.97-23.2 months).

Evaluation of the first response to treatment revealed: 1 (2.6\%) patient - total remission, 15 (38.5\%) patients - partial remission, 14 (35.9\%)

Table II. Patients by site of metastases

\begin{tabular}{|lcc|}
\hline Site of metastasis & $\begin{array}{c}\text { Number } \\
\text { of patients }\end{array}$ & $\begin{array}{c}\text { Percentage } \\
\text { of patients }\end{array}$ \\
\hline Lungs & 26 & 66.7 \\
\hline Lymph nodes & 19 & 48.7 \\
\hline Liver & 9 & 23.1 \\
\hline Soft tissues & 24 & 61.5 \\
\hline Bones & 11 & 28.2 \\
\hline
\end{tabular}


Table III. Adverse events of all grades during treatment (according to CTCAE 4.0) [12]

\begin{tabular}{|c|c|c|}
\hline Adverse event & $\begin{array}{l}\text { Number } \\
\text { of patients }\end{array}$ & $\begin{array}{l}\text { Percentage } \\
\text { of patients }\end{array}$ \\
\hline Thrombocytopenia & 13 & 33.3 \\
\hline Hypertension & 17 & 43.6 \\
\hline Pulmonary embolism & 0 & 0 \\
\hline Deep vein thrombosis & 2 & 5.1 \\
\hline Bleeding & 3 & 7.7 \\
\hline Neutropenia & 15 & 38.5 \\
\hline Fatigue & 13 & 33.3 \\
\hline Diarrhea & 2 & 5.1 \\
\hline Stomatitis & 13 & 33.3 \\
\hline Swelling of the eyelids & 6 & 15.4 \\
\hline Vomiting & 4 & 10.3 \\
\hline $\begin{array}{l}\text { HFSR (hand-foot skin } \\
\text { reaction) }\end{array}$ & 5 & 12.8 \\
\hline Yellowing of the skin & 4 & 10.3 \\
\hline Anemia & 1 & 2.6 \\
\hline $\begin{array}{l}\text { Other (nausea, } \\
\text { increase in liver } \\
\text { enzymes, itching of } \\
\text { the skin, headache) }\end{array}$ & 6 & 15.4 \\
\hline
\end{tabular}

Table IV. Serious adverse events (Grades 3-4) during treatment (according to CTCAE 4.0) [12]

\begin{tabular}{|lcc|}
\hline Adverse event & $\begin{array}{c}\text { Number } \\
\text { of patients }\end{array}$ & $\begin{array}{c}\text { Percentage of } \\
\text { all patients }\end{array}$ \\
\hline Thrombocytopenia & 1 & 2.6 \\
\hline Hypertension & 4 & 10.3 \\
\hline Neutropenia & 3 & 7.7 \\
\hline Fatigue & 4 & 10.3 \\
\hline Stomatitis & 2 & 5.1 \\
\hline $\begin{array}{l}\text { Increase in liver } \\
\text { enzymes }\end{array}$ & 1 & 2.6 \\
\hline
\end{tabular}

patients - stabilization of disease, 6 (15.4\%) patients - progression, $3(7.7 \%)$ patients - no evaluation; 1 patient was lost to follow-up, 2 patients discontinued treatment because of adverse events, and imaging studies were postponed until resolution of symptoms.

\section{Discussion}

Based on the analysis, the most common adverse events were hypertension, neutropenia, thrombocytopenia, fatigue, and stomatitis (Table III). Adverse events that appeared during treatment did not reach the Grade 4 according to CTCAE 4, and grade 3 events affected up to $10 \%$ of patients (Table IV). We did not record pulmonary embolism or bleeding from the tumors.

Eight (20.5\%) patients did not receive further treatment because of the following adverse events: hypertension in 2 cases, stomatitis in 1 , hand-foot syndrome in another 1 , asthenia in 2 patients, vomiting in 1 and exacerbation of neurological symptoms (see below). All these adverse events were classified as Grade 3 toxicity and were resistant to symptomatic treatment.

In Motzer et al.'s study, therapy was discontinued in $19 \%$ of patients because of adverse effects and in Gore et al.'s study $8 \%$ of patients discontinued $[8,13]$.

In 1 patient, further treatment was discontinued because of an exacerbation of neurological symptoms (tetraparesis), and in the statistical analysis the patient was assigned to the group that discontinued treatment because of adverse events. We do not associate these symptoms with sunitinib administration, however, as they appeared prior to treatment. The patient was diagnosed with cervical spinal stenosis.

All patients with previously diagnosed arterial hypertensive disease had to have normal blood pressure at the time of initiation of sunitinib. Arterial hypertension as an adverse event of sunitinib was defined as an increase in blood pressure above the normal range, the necessity of increasing doses of hypertensive drugs or the necessity of adding another drug. Grade 3 hypertension occurred in $4(10.3 \%)$ patients whereas Motzer et al. [8] found it in $12 \%$, and Gore et al. [13] in 5\%. According to Rini et al., this symptom is associated with a better response rate, and longer PFS and OS [14]. Physiologically, vascular endothelial growth factor (VEGF) plays a role in blood pressure regulation by its influence on vasorelaxation or vasodilation. This process is regulated by nitric oxide [15]. Inhibition of VEGF by sunitinib leads to vasoconstriction as a result of reduced bioavailability of nitric oxide. There is also a suggestion that hypertension is a result of reduced renal excretion of sodium and water, reduced endothelial function and an elevated level of endothelin-1 $[16,17]$.

In 2 of 4 patients with grade 3 hypertension, treatment was discontinued because of resistant hypertension (uncontrolled disease despite the use of three or more antihypertensive drugs including diuretics). In these cases blood pressure returned to a normal level after stopping sunitinib but continuation of antihypertensive drugs was necessary.

In the other 2 patients, treatment continued because pharmacological equalization of the ele- 
vated blood pressure was achieved and the sunitinib dose was reduced to $25 \mathrm{mg} /$ day. Normalization of blood pressure was possible by using combinations of drugs with different mechanisms of action. In these cases it was necessary to use ACE inhibitors (or sartans), $\beta$-blockers, diuretics and a calcium channel blocker.

Grade 3 thrombocytopenia occurred in 1 (2.6\%) patient; in the literature, this symptom was observed slightly more frequently: 6-9\%, according to data from Motzer et al., Gore et al. and others $[8,13,18-22]$.

Grade 3 neutropenia occurred in $3(7.7 \%)$ patients; in other studies, the frequency was 8-13\% $[8,13,18,19,21-23]$.

Hematologic toxicity may be a result of inhibition of receptors expressed on hematopoietic stem cells (KIT, PDGFR, FLT3) [24].

There are reports that the occurrence of neutropenia or/and thrombocytopenia is connected with prolonging time to progression, overall survival and progression-free survival [25].

High-grade fatigue affected 4 (10.3\%) patients; in other studies, this high-grade adverse event occurred with a frequency of $7-10 \%[13,18,19,21]$.

According to data from published studies, weakness during sunitinib treatment is often a symptom of hypothyroidism [26]. According to data provided by Kollmannsberger et al. [21] and Eisen et al. [27], in $85 \%$ of patients treated with sunitinib, the values of any studied thyroid hormone are incorrect, but clinical signs of hypothyroidism are not always apparent. Originally, we did not determine the level of thyroid-stimulating hormone (TSH); thus, it is difficult to assess in how many patients weakness was caused by the treatment and in how many by reduced levels of free thyroid hormones. Currently, the TSH level is routinely determined for each patient starting treatment.

High-grade stomatitis affected 2 (5.1\%) patients; in data from other authors, this percentage was $1-5 \%[18,19]$.

In the treated patients, 8 (20.5\%) required dose reduction to $25 \mathrm{mg}$ /day because of adverse events: 2 had hypertension, 2 had increased liver enzyme levels, and the following events occurred one each in a single patient: stomatitis, weakness, neutropenia, and anemia. In each of these patients, the adverse event resolved sufficiently to allow continued therapy.

Adverse events of grade lower than Grade 3 resolved spontaneously or with symptomatic treatment. None led to the interruption of treatment (for example treatment of arterial hypertension according to guidelines [28]).

In conclusion, in the analyzed group of 39 patients, sunitinib malate treatment was effective in prolonging survival time and time to disease progression. The toxicity associated with treatment that was observed in this group is comparable with the data reported by other authors. The experience with this drug allows better prophylaxis and treatment of side effects.

\section{Conflict of interest}

The authors declare no conflict of interest.

\section{References}

1. Didkowska J, Wojciechowska U, Zatoński W. Cancer in Poland in 2009. Cancer Center and Institute of Oncology, Warsaw 2011.

2. Ljungberg B, Hanbury DC, Kuczyk MA, et al. Guidelines on Renal Cell Carcinoma. European Association of Urology, 2009. http://www.uroweb.org/fileadmin/tx_eauguidelines/2009/Full/RCC.pdf

3. Eble JN, Sauter G, Epstein JI, et al. World Health Organization classification of tumors. Pathology and genetics of tumors of the urinary system and male genital organs. IARC Press, Lyon 2004: 9-88.

4. Edge SB, Byrd DR, Compton CC, et al. (eds.). The AJCC Cancer Staging Manual and Handbook. 7th ed. Springer New York Dordrecht Heidelberg London, 2010.

5. Motzer RJ, Mazumdar M, Bacik J, et al. Survival and prognostic stratification of 670 patients with advanced renal cell carcinoma. J Clin Oncol 1999; 17: 2530-40.

6. Giberti C, Oneto F, Martorana G, et al. Radical nephrectomy for renal cell carcinoma: long-term results and prognostic factors on a series of 328 cases. Eur Urol 1997; 31: 40-8.

7. Flanigan RC, Mickisch G, Sylvester R, et al. Cytoreductive nephrectomy in patients with metastatic renal cancer: a combined analysis. J Urol 2004; 171: 1071-6.

8. Motzer RJ, Hutson TE, Tomczak P, et al. Overall survival and updated results for sunitinib compared with interferon alfa in patients with metastatic renal cell carcinoma. J Clin Oncol 2009; 27: 3584-90.

9. Motzer RJ, Agarwal N, Beard C, et al.; National Comprehensive Cancer Network. Kidney cancer. J Natl Compr Canc Netw 2011; 9: 960-77.

10. National Cancer Institute. Stage IV and recurrent renal cell cancer. http://www.cancer.gov/cancertopics/pdq/ treatment/renalcell/HealthProfessional/page8.

11. Stelmach A, Wysocki PJ, Fijuth J, et al. Renal cell carcinoma. In: Recommendations for clinical and therapeutic procedures in cancer. Krzakowski M, Warzocha K (eds.). Via Medica, Gdansk 2013; 369-77.

12. Common Terminology Criteria for Adverse Events (CTCAE) Version 4.0. Published: May 28, 2009 (v4.02: Sept. 15, 2009).

13. Gore ME, Szczylik C, Porta C, et al. Safety and efficacy of sunitinib for metastatic renal-cell carcinoma: an expanded-access trial. Lancet Oncol 2009; 10: 757-63.

14. Rini BI, Cohen DP, Lu DR, et al. Hypertension as a biomarker of efficacy in patients with metastatic renal cell carcinoma treated with sunitinib. J Natl Cancer Inst 2011; 103: 763-73.

15. Wei W, Jin H, Chen ZW, et al. Vascular endothelial growth factor-induced nitric oxide- and PGI2-dependent relaxation in human internal mammary arteries: a comparative study with KDR and Flt-1 selective mutants. J Cardiovasc Pharmacol 2004; 44: 615-21. 
16. Van Heeckeren WJ, Ortiz J, Cooney MM, Remick SC. Hypertension, proteinuria, and antagonism of vascular endothelial growth factor signaling: clinical toxicity, therapeutic target, or novel biomarker? J Clin Oncol 2007; 25: 2993-5.

17. Kappers MH, van Esch JH, Sluiter W, Sleijfer S, Danser $\mathrm{AH}$, van den Meiracker $\mathrm{AH}$. Hypertension induced by the tyrosine kinase inhibitor sunitinib is associated with increased circulating endothelin-1 levels. Hypertension 2010; 56: 675-81.

18. Ivanyi P, Winkler T, Ganser A, et al. Novel therapies in advanced renal cell carcinoma: management of adverse events from sorafenib and sunitinib. Dtsch Arztebl Int 2008; 105: 232-7.

19. Motzer RJ, Hutson TE, Tomczak P, et al. Sunitinib versus interferon alfa in metastatic renal-cell carcinoma. N Engl Med 2007; 356: 115-24

20. Ravaud A. Treatment-associated adverse event management in the advanced renal cell carcinoma patient treated with targeted therapies. Oncologist 2011; 16 Suppl. 2: 32-44.

21. Kollmannsberger C, Bjarnason G, Burnett P, et al. Sunitinib in metastatic renal cell carcinoma: recommendations for management of noncardiovascular toxicities. Oncologist 2011; 16: 543-53.

22. Schwandt A, Wood LS, Rini B, Dreicer R. Management of side effects associated with sunitinib therapy for patients with renal cell carcinoma. Onco Targets Ther 2009; 2: 51-61.

23. Motzer RJ, Rini BI, Bukowski RM, et al. Sunitinib in patients with metastatic renal cell carcinoma. JAMA 2006; 295: 2516-24.

24. Aparicio-Gallego G, Blanco M, Figueroa A, et al. New insights into molecular mechanisms of sunitinib-associated side effects. Mol Cancer Ther 2011; 10: 2215-23.

25. Donskov F, Cams A, Barrios CH, et al. Neutropenia and thrombocytopenia during treatment as biomarkers of sunitinib efficiacy in a papients with metastatic renal cell carcinoma (mRCC). Poster presentation at the European Multidisciplinary Cancer Congress 2011, abstract 1141.

26. Rini BI, Tamaskar I, Shaheen P, et al. Hypothyroidism in patients with metastatic renal cell carcinoma treated with sunitinib. J Natl Cancer Inst 2007; 99: 81-3.

27. Eisen T, Sternberg CN, Robert C, et al. Targeted therapies for renal cell carcinoma: review of adverse event management strategies. J Natl Cancer Inst 2012; 104: 93-113.

28. Aronow W. Commentary on recent guidelines for treating hypertension. Arch Med Sci 2014; 10: 1069-72. 